\title{
On the Coexistence of Banks and Markets
}

\section{Hans Gersbach* Harald Uhlig**}

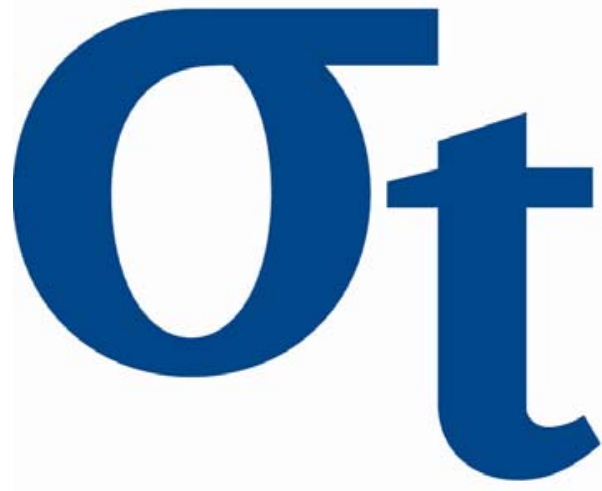

)

$\forall$

$(0$

* University of Heidelberg and CEPR

** Humboldt-Universität zu Berlin, Deutsche Bundesbank, CentER and CEPR

This research was supported by the Deutsche Forschungsgemeinschaft through the SFB 649 "Economic Risk".

http://sfb649. wiwi. hu-berlin.de ISSN 1860-5664 


\title{
On the Coexistence of Banks and Markets*
}

\author{
Hans Gersbach \\ University of Heidelberg and CEPR \\ and \\ Harald Uhlig \\ Humboldt University, Berlin, \\ Deutsche Bundesbank, CentER and CEPR
}

Keywords: contract, debt contract, adverse selection, moral hazard, coexistence of financial intermediaries, regulation

JEL codes: G24, G28, G32, G38, D80, D92, D43

This version: March 2006

\footnotetext{
*We would like to thank Hendrik Ballhausen, Alexandrina Braack, Patrick Bolton, Dirk Hackbarth, Volker Hahn, Holgar Mueller, Massoud Mussavian, Eva Terberger-Stoy, a CentER referee, seminar participants at the London Business School and in Berlin, and the referees for their helpful comments. This research was supported by the Deutsche Forschungsgemeinschaft through the SFB 649 "Economic Risk". The addresses of the authors are Hans Gersbach, Grabengasse 14, University of Heidelberg, Germany, gersbach@uni-hd.de, and Harald Uhlig, Humboldt University, Berlin, Unter den Linden 6, D-10099 Berlin, Germany.
} 


\begin{abstract}
We examine the coexistence of banks and financial markets, studying a credit market where the qualities of investment projects are not observable and the investment decisions of entrepreneurs are not contractible. Standard banks can alleviate moral-hazard problems by securing a portion of a repayment in the case of non-investment. Financial markets operated by investment banks and rating agencies have screening know-how and can alleviate adverse-selection problems. In competition, standard banks are forced to increase repayments, since financial markets can attract the highest-quality borrowers. This, in turn, increases the share of shirkers and may make lending unprofitable for standard banks. The coexistence of financial markets and standard banks is socially inefficient. The same inefficiency can happen with the entrance of sophisticated banks, operating with a combination of rating and ongoing monitoring technologies.
\end{abstract}




\section{Introduction}

We consider a credit market in which creditors can neither observe the quality of investment projects, nor whether entrepreneurs are investing and thus generating large enough returns to pay back their loans. Lenders therefore face a combined adverse-selection and moral-hazard problem. We examine how banks and financial markets compete in this credit market. The first type, called the standard commercial bank (henceforth standard bank), can act as a delegated monitor in the sense of the term used by Diamond (1984) and can reduce the private benefits of entrepreneurs who do not invest. Therefore standard banks can alleviate moral hazard problems. Standard banks, however, face competition from financial markets, whereas investment banks and rating agencies are able to assess projects and at some cost can determine the quality of investment projects. We examine whether it is socially desirable for financial markets and standard banks to be present simultaneously.

Moreover, the current banking regulation in Basel II forces banks to become more sophisticated in the screening and rating of entrepreneurs. Hence we will also investigate the consequences for welfare when sophisticated banks that combine screening and monitoring technologies enter the scene.

Our conclusions are: First, if the pool of entrepreneurs is good enough, standard banks competing with other standard banks only will offer loans to all entrepreneurs. Second, if only financial markets are present and screening costs are not too high, only borrowers with the best projects will obtain credit. Third, in competition standard banks are forced to increase repayments, since financial markets can attract the highest quality borrowers. This, in turn, increases the share of shirkers, which is socially inefficient if social welfare is measured by aggregate production. If standard banks and financial markets coexist, social efficiency is always lower compared to a situation where only standard banks exist. Regulations prohibiting the coexistence of banks and specialized lenders might be beneficial. 
Fourth, if the attractiveness of the remaining pool of entrepreneurs for standard banks decreases too much when financial markets are present, standard banks will drop out of the market. Entrepreneurs with intermediate qualities will not obtain loans, even if they have valuable projects. Since the presence of financial markets prevents intermediate-quality entrepreneurs from obtaining loans due to the exit of standard banks, the presence of financial markets can again create social inefficiencies.

To sum up, the presence of financial markets can create social inefficiencies, since the share of shirkers may increase or intermediate borrowers may not be able to obtain loans. Finally, we discuss the issue of whether sophisticated banks with access to both types of monitoring technologies might obviate the social inefficiencies created by financial markets. Fostering the development of such banks is one of the main objectives of Basel II. We show that, depending on parameters, sophisticated banks either act as separate financial markets and standard banks, thus producing the same social inefficiencies, or they use both monitoring technologies, which definitively improves welfare.

\section{Motivation and Relation to the Literature}

Our paper is related to different strands in the literature. Its first subject is about competition between banks. Comprehensive surveys on bank competition can be found in Bhattacharya and Thakor (1993), Hellwig (1994), Bhattacharya, Boot and Thakor (1998), and Allen and Santomero (1998). We branch out from this literature by considering the coexistence of financial intermediaries with different specializations in the presence of moral hazard and adverse selection. ${ }^{1}$ We show that the interaction of adverse selection and moral

\footnotetext{
${ }^{1}$ The coexistence of financial institutions is an issue in other contexts. E.g., Black and Gilson (1998) provide a comprehensive account of the role of venture capitalists in financial markets. Berger, Demsetz and Strahan (1998) and Berger (2000) provide comprehensive analysis of the forces and barriers related to the integration of the financial service industry.
} 
hazard creates social inefficiencies in credit markets when standard banks compete with financial markets or sophisticated banks.

Second, Boot and Thakor (2000) examine whether relationship banking that involves unique bank-specific services can survive competition from transaction lending. They show that a bank's optimal response to increased competition is to expand its relationship lending relative to its transaction lending. Therefore the argument that relationship lending will be driven out of the market by competition with transaction lending is premature. Boot (2000) provides a comprehensive survey of the issues. Our work is complementary, since we focus on another possible type of specialization with regard to the handling of adverse selection and moral hazard.

Third, a wealth of research has addressed and enlarged upon the co-existence of bank lending and bond financing: Besanko and Kanatas (1993), Hoshi, Kashyap, and Scharfstein (1993), Chemmanur and Fulghieri (1994), Boot and Thakor (1997a), Holmström and Tirole (1997), von Thadden (1999), Repullo and Suarez (2000), Bolton and Freixas (2000), and Allen and Gale (2004). Our main contribution to this literature is to examine the coexistence of banks and financial markets when the pool of borrowers is plagued simultaneously by moral hazard and adverse selection.

Fourth, another important source of literature has been the coexistence of commercial banking and underwriting securities studied in Kroszner and Rajan (1994), Puri (1994, 1999), Boot and Thakor (1997b), and more recently by Kanatas and Qi (1998) and (2000). This literature identifies the circumstances under which the combination of commercial lending and underwriting securities within sophisticated banks reduces their incentives (relative to those of specialized intermediaries) to undertake financial innovation aimed at helping to sell their client's securities. There may however be informational economies of scope between the banking activities. Our paper is complementary to this literature. Although in our model a sophisticated bank can simultaneously alleviate moral-hazard and adverse-selection problems, it might simply behave 
like investment banks so as to emulate financial markets. Our analysis also highlights the cost levels of screening and interim monitoring at which the integration of financial services takes place.

We interpret standard banks as commercial banks. Such banks acquire knowledge of how to inspect the firms' cash flow when customers pay, or they collateralize assets if they are created in the process of investing or selling products. $^{2}$ In financial markets, investment banks and rating agencies specialize in screening entrepreneurs with creditworthiness tests. Investment banks and rating agencies do not engage in the continuous monitoring of investment behavior. Thus financial markets with investment banks and rating agencies can mainly alleviate adverse-selection problems. ${ }^{3}$ Accordingly, our analysis points up the potential negative feedback effects from banking regulation in the form of the new Accord Basel II that aims at increasing the sophistication of banks with respect to their screening and rating capabilities. As our model indicates, such attempts at banking regulation may not produce welfare gains if sophisticated banks tend to specialize in investment banking and threaten the economic role of standard commercial banks. Even if standard banks can survive, the proportion of shirkers in the economy will increase.

The paper proceeds as follows: In the next section we outline the model. Then we separately examine standard banks in section 4 and financial markets in section 5. In section 6, the coexistence of standard banks and financial markets is discussed. In section 7 we examine sophisticated banks. Section 8 concludes.

\footnotetext{
${ }^{2}$ See James (1987) and Lummer and McConnell (1989) for evidence that private information about their borrowers is generated by commercial banks during lending.

${ }^{3}$ The informational role of underwriters is shown, for example, in Beatty and Ritter (1986), Booth and Smith (1986), and Carter and Manaster (1990). It is clear that commercial banks also invest resources in screening potential borrowers. Accordingly, when we examine sophisticated banks we take account of their screening role as well.
} 


\section{Model}

There are two periods, this period and the next period. We consider a finite number $k$ of entrepreneurs who have access to a project but do not have the funds to finance it. Entrepreneurs are of different types $j=1, \ldots, n$. Entrepreneurs of type $j$ have a quality of $q_{j} \geq 0$. The probability that an entrepreneur is of type $q_{j}$ is denoted by $\gamma_{j}$. To simplify notation we present our results normalized by the number of entrepreneurs, i.e. we set $k=1{ }^{4}$

Qualities are labeled so that $0 \leq q_{1}<q_{2}<\cdots<q_{n}$, i.e. qualities $q_{j}$ are strictly increasing in $j$. All projects are of equal size. Suppose that the initial costs for each project are $I+z$, but the entrepreneur's initial wealth is only $z$. Hence, an entrepreneur must borrow at least $I$ for the project.

Given additional resources $I>0$, he can choose to invest $\left(\delta_{j}=1\right)$ or not $\left(\delta_{j}=0\right)$. If he invests in this period, he receives the output

$$
(I+z) \cdot q_{j}
$$

in the next period. If the entrepreneur does not invest, the available funds are simply $I+z$. Entrepreneurs cannot have negative wealth in the next period.

Entrepreneurs can borrow additional funds from standard banks or from financial markets operated by investment banks. Lenders face the following informational asymmetries if they decide not to invest in monitoring: The quality $q_{j}$ is known to the entrepreneur but not to lenders. Moreover, lenders cannot observe a priori whether or not an entrepreneur invests. Thus creditors face a fixed pool of seemingly identical borrowers. Lenders, however, can only observe and verify realized cash flows in the next period if the entrepreneur invests. If the entrepreneur does not invest but simply consumes the funds granted to him, lenders cannot expect any repayment.

It is useful to discuss the main assumptions of our model. The nonverifiability of the investment decision is a standard scenario. Projects often

\footnotetext{
${ }^{4}$ To represent our results in absolute terms, all expressions for profits and welfare must be multiplied by $k$.
} 
require specific human capital, or they may need the design of blueprints for machinery, buildings, or logistics. In the case of an inventor, the person in question may spend a lot of time reading and designing. Whether these efforts are directed toward the project and whether blueprints are competently drafted is unlikely to be observable for a standard bank. Even if it becomes clear to the standard bank ex post whether or not the entrepreneur has invested, investment decisions are not verifiable in court.

The second assumption of our model is that the verification of output conditional on investment is possible at low or zero costs, while entrepreneurs have large private benefits if they do not invest. The assumption is justified by the possibilities available to standard banks of securing the repayments if entrepreneurs invest. Monitoring to secure repayments takes many forms: inspection of firms' cash flow when customers pay, and efforts to collateralize assets if they have been created in the process of investing and selling products to customers. If the final products of an entrepreneur's project are physical goods, such as houses or machines, standard banks can secure repayment conditional on investment at very low costs. For simplicity, we assume that the costs of verifying cash flow are zero if the entrepreneur has invested. For the same reason, we assume that the repayment will be zero if entrepreneurs do not invest but simply consume the funds, as long as lenders do not invest in monitoring. Our assumption - non-verifiability of investments, but verifiability of project output - is a simple way of modeling moral hazard. Two remarks about our modeling approach are in order. One could introduce an arbitrarily small probability $\varepsilon(\varepsilon>0)$ such that investment returns are 0 with probability $\varepsilon$ and $q_{j}(I+z)$ with probability $1-\varepsilon$. This would strengthen the non-verifiability of investment assumptions. ${ }^{5}$ Second, as documented in the empirical banking literature, monitoring activities to ensure promised invest-

\footnotetext{
${ }^{5}$ Since entrepreneurs can consume their funds when they do not invest, there is no way for banks to punish non-investing entrepreneurs because they can always claim that their investments were unsuccessful.
} 
ment activities by borrowers and to prevent funds from being diverted is an important aspect of the activities of commercial banks (see e.g. James (1987), Lummer and McConell (1989), Petersen (2004), Berger and Udell (2002)).

Standard banks and financial markets specialize in certain monitoring technologies. Standard commercial banks act as delegated monitors and alleviate the moral-hazard problem to some extent by securing non-zero repayment if entrepreneurs do not invest.

Investment banks and rating agencies operating in financial markets specialize in alleviating adverse-selection problems. They can screen entrepreneurs by creditworthiness tests (see Bröcker (1990)) and then decide whether or not to issue debt on behalf of entrepreneurs. In contrast to standard banks, investment banks in financial markets only interact with entrepreneurs at the stage when debt contracts are issued and do not engage in continuous monitoring of investment behavior.

Crucial for our analysis is the fact that agents in financial markets may tend to specialize in alleviating moral-hazard or adverse-selection problems. For instance, a rating agency or an investment bank acquires knowledge about industries in which borrowers are engaged and can therefore perform reliable creditworthiness tests. Other financial institutions, such as commercial banks, acquire knowledge of how to inspect the firms' cash flow when customers pay, or they invest in efforts to collateralize assets if they are created in the process of investing or selling products. The exact nature of these different specializations by financial institutions will be discussed in the following sections.

There are potentially $H$ standard banks indexed by $i$ or $h$ with $i, h=$ $1, \ldots, H$ that can enter the credit market, and financial markets are operated by investment banks. Standard banks and investors in capital markets are assumed to be risk-neutral. For simplicity of presentation, the opportunity cost of funds is normalized to zero. We summarize the game as follows: 
1. Standard banks and investment banks operating financial markets simultaneously decide whether or not to enter and which contract to offer to investors upon entering.

2. Entrepreneurs simultaneously choose standard banks or choose to borrow from financial markets via investment banks.

3. Banks finance themselves at the opportunity cost of funds. Funded entrepreneurs make a decision on whether to invest.

4. Payoffs are realized and repayments occur.

An equilibrium of this game is a pure-strategy, subgame-perfect Bayesian Nash equilibrium. It is a self-selection model where standard sorting devices, such as collateral (see Bester (1985), Bester (1987)), cannot be used to separate bad entrepreneurs from good ones. ${ }^{6}$

We additionally assume four tie-breakers in the case of indifference on the part of the entrepreneurs. We describe them briefly here and in greater detail in the analysis below. First, entrepreneurs who are indifferent between investing and not investing always choose to invest. Second, investing entrepreneurs who are indifferent between several standard banks or between several contracts issued by investment banks on behalf of entrepreneurs will choose between standard banks or investment banks with equal probability. Third, entrepreneurs who are indifferent between standard banks and financial markets will go to financial markets. Fourth, entrepreneurs who choose not to invest will randomize across their preferred standard banks in order to mimic the investing entrepreneurs. ${ }^{7}$ The first three tie-breaker rules are

\footnotetext{
${ }^{6}$ Such models have been introduced by Rothschild and Stiglitz (1976) and Stiglitz and Weiss (1981). Hellwig (1987) provides a detailed discussion of the existence problems in such models.

${ }^{7}$ Since investment banks operating financial markets can screen projects, they will be able to avoid and reject shirkers applying for credit contracts.
} 
standard and innocuous, while the fourth tie-breaker rule is critical to the analysis and will be discussed in more detail when we examine competition in the credit market.

We conclude the description of the game by deriving the first-best allocation. For that purpose, we assume that there is a fixed pool of savings, denoted by $S$. We assume that savings exceed the volume of loans if all entrepreneurs have obtained a credit. Since we have normalized the number of entrepreneurs, $k$, to 1 , the condition amounts to $S>I .{ }^{8}$ All savings not channeled to entrepreneurs are assumed to be invested in a frictionless technology that generates the opportunity costs of funds. Then welfare is defined as the value of aggregate resources in stage 4 . Let $j^{*}=\min \left\{j \mid q_{j} \geq 1\right\}$. Hence $j^{*}$ is the first index value for which the return of the investment project is greater than, or equal to, the opportunity costs of funds. The first-best solution is characterized by the absence of informational functions and by a social planner granting loans and enforcing investment decisions in order to maximize aggregate output.

Proposition 1 The first-best solution is characterized as follows: An entrepreneur obtains a loan and has to invest if, and only if, $q_{j} \geq 1$, i.e., iff $j \geq j^{*}$.

In other words, the social planner dictates that there should be investment in all those projects that at least meet the opportunity costs. The proposition is obvious. Welfare in the first-best allocation, denoted by $W^{F B}$, is given by

$$
W^{F B}=\sum_{j \geq j^{*}} \gamma_{j} q_{j}(I+z)+\left(S-\left(\sum_{j \geq j^{*}} \gamma_{j}\right) I\right)+\left(\sum_{j<j^{*}} \gamma_{j}\right) z
$$

The first term in $W^{F B}$ represents the output of entrepreneurs who have

\footnotetext{
${ }^{8}$ Note that banks are assumed to have unlimited access to funds at a zero interest rate. As credit decisions are taken before banks finance themselves, the condition $S>I$ ensures that no bank will be rationed by deposits.
} 
received loans and have invested. The last two terms capture the output from investing the remaining funds in the frictionless technology.

\section{Standard Banks Only}

In this section we study competition between standard banks. We assume that these banks offer debt contracts. A theoretical justification is given in Gersbach and Uhlig (2004), which can easily be extended to standard banks with monitoring technologies, such as those considered in this paper.

A debt contract offered by bank $i \quad(i=1, \ldots, H)$, denoted by $D\left(R_{i}\right)$, is characterized by a repayment $R_{i}$ that is independent of the type $j$. Moreover, under a debt contract the standard bank $i$ obtains $q_{j}(I+z)$ if the entrepreneur has invested but cannot pay back $R_{i}$ since control will shift to the creditor.

Standard banks are assumed to have access to a monitoring technology. If a bank offers a loan contract to an entrepreneur and pays a resource cost $m, m \geq$ 0 , it can secure a repayment of $\alpha I(0<\alpha \leq 1)$ from the entrepreneur if he does not invest. Hence, a non-investing entrepreneur only obtains $z+(1-\alpha) I$. If the entrepreneur invests, the bank obtains $\min \left\{R_{i}, q_{j}(I+z)\right\}$. Note that the resource cost $m$ has to be paid before the bank observes shirking on the part of entrepreneurs. We assume throughout the paper that $m$ is small enough for standard banks always to decide to monitor when they grant loans. A necessary condition is $m<\alpha I .^{9}$

Consider an entrepreneur of type $j$. If there is at least one contract for which investing is weakly better than not investing, we assume that the entrepreneur will always choose to invest (this is the first tie-breaker mentioned above) and will select any of the standard banks at which the payoff is maximized with equal probability (this is the second tie-breaker mentioned above).

\footnotetext{
${ }^{9}$ If we use $F(q)$ to denote the proportion of entrepreneurs with $q_{j}>q$, a sufficient condition is $m<\alpha I F(1)$, since the proportion of shirkers standard banks face is at least $F(1)$.
} 
All entrepreneurs for whom not investing is strictly better than investing are shirkers and will not invest. Shirkers will choose the standard bank offering the highest payoff. Hence they prefer standard banks that do not monitor to standard banks that invest in monitoring. They are indifferent among the set of standard banks if, as we have assumed, all standard banks invest in monitoring.

To break that indifference we employ our fourth tie-breaker rule. We assume that shirkers distribute themselves across the standard banks in exactly the same way as investors do. A justification for this assumption is given in Gersbach and Uhlig (2004). ${ }^{10}$

Bertrand competition will ensure that in any equilibrium standard banks will demand the same repayment, which is denoted by $R^{b}$. The entrepreneur who is indifferent between investing and not-investing when applying for a standard bank credit is denoted by $q^{S B}$ and given by

$$
\begin{aligned}
q^{S B}(I+z)-R^{b} & =(1-\alpha) \cdot I+z \\
q^{S B} & =1+\frac{R^{b}-\alpha I}{I+z}
\end{aligned}
$$

Note that $q^{S B}$ increases with the repayment because a higher repayment will increase the incentive to shirk. The expected profits for standard banks are denoted by $G^{b}\left(R^{b}\right)$ and are given by

$$
G^{b}\left(R^{b}\right)=\sum_{q_{j}<q^{S B}\left(R^{b}\right)} \gamma_{j}(\alpha I-I-m)+\sum_{q_{j} \geq q^{S B}\left(R^{b}\right)} \gamma_{j}\left(R^{b}-I-m\right)
$$

Let $R^{*}$ be the interest rate standard banks will charge under Bertrand competition. The standard Bertrand undercutting argument implies that

$$
R^{*}=\min \left\{R \mid G^{b}(R) \geq 0\right\}
$$

\footnotetext{
${ }^{10}$ If all entrepreneurs are shirkers, we assume that shirkers distribute themselves arbitrarily across standard banks. Since this case does not occur in equilibrium or in any relevant deviation strategies, the assumption is harmless.
} 
Equation 1 implies that $R^{*}$ exists if the pool of investors is of sufficiently high quality and/or the monitoring technology in terms of the pair $(\alpha, m)$ is sufficiently effective, i.e. if $\alpha$ is sufficiently high and $m$ comparatively low. We summarize our observations in the following proposition:

Proposition 2 Suppose that $R^{*}$ exists and that only standard banks are present. Then there exists a unique equilibrium in which standard banks offer debt contracts at repayment $R^{*}$.

In the following we assume that $R^{*}$ exists. Otherwise, there would be no economic role for standard banks.

\section{$5 \quad$ Financial Markets Only}

In this section we assume that there is a finite number of investment banks that operate financial markets. An investment bank has access to a creditworthiness test. If an investment bank invests $c>0$ per credit, it can detect the quality of the project when the entrepreneur applies for a debt contract and has the option of issuing debt on behalf of the entrepreneur. We interpret $c$ as the overall cost of a creditworthiness test and placement and settlement of one debt contract. Different levels of $c$ may be associated with different levels of financial development. A high level of $c$ corresponds to financial institutions where direct financing operated by investment banks is less highly developed. There are two options for investment banks entering into an agreement with a borrower. First, they can decide to undertake a creditworthiness test and then decide whether to issue debt contracts on behalf of the entrepreneurs by pledging the entrepreneurs' capacity to pay back consumers. Second, they can issue debt contracts themselves and then decide whether to undertake a creditworthiness test and to offer debt contracts to a borrower. We work here with the first variant because it is closer to the actual behavior of financial markets. 
We assume that investment banks either perform a creditworthiness test before issuing debt on behalf of investors, or they do not enter the market. ${ }^{11}$ Obviously, an investment bank will only issue debt on behalf of investors if the project is of sufficiently high quality. Let $q^{F M}$ denote the critical quality level above which entrepreneurs receive credit. A credit contract offered by an investment bank on behalf of investors is denoted by $C^{v}\left(R_{q_{j}}^{v}, q_{j} \geq q^{F M}\right)$. $R_{q_{j}}^{v}$ is the repayment demanded from an entrepreneur that turns out to be of quality $q_{j} \geq q^{F M}$ when screened by an investment bank. The expected profit of a bank from a loan to an entrepreneur with quality level $q_{j}$ who invests is given by $G_{q_{j}}^{v}=R_{q_{j}}^{v}-I-c$.

We assume that the entrepreneur is charged with the costs of the creditworthiness test up front, which he must then pay for from his initial wealth $z$. If the test turns out to be positive, i.e. $q \geq q^{F M}$, the investment bank grants a credit of $I+c$. If the test yields $q<q^{F M}$, the entrepreneur bears the cost.

The assumption allows investment banks to deter entrepreneurs of lower quality than $q^{F M}$ from applying for credit. Otherwise, investment banks would need to be concerned about the incentives of entrepreneurs with $q<q^{F M}$ for applying for creditworthiness tests. Once an investment bank performs the test, pays $c$, and discovers that $q<q^{F M}$, the entrepreneur could negotiate a lower repayment with the investment bank because $c$ is sunk. We obtain

Proposition 3 Suppose that only financial markets operated by investment banks are present. Then there exists a unique equilibrium with

$$
\begin{aligned}
R_{q_{j}}^{v}= & R^{v *}=I+c \\
q^{F M *} & =1+\frac{I+c}{I+z}
\end{aligned}
$$

The proof of Proposition 3 is given in the appendix. Proposition 3 shows that only entrepreneurs with $q \geq q^{F M *}$ will have access to financial markets. Financial markets avoid shirkers but limit access to the market.

\footnotetext{
${ }^{11}$ The screening condition requires that the screening costs $c$ be below some critical level that can be determined by using the next propositions.
} 


\section{Standard Banks and Financial Markets}

In this section we examine the coexistence of standard banks and financial markets. Because of the Bertrand competition between standard banks, we simplify the derivation by assuming that all standard banks offer the same interest rate, denoted by $R^{b}$. Obviously, we have to show that in the proposed equilibria no standard bank wants to deviate.

To determine the equilibria we proceed in two steps. First, we determine the profits of standard banks under the assumption that repayments to the said banks will always be higher than in financial markets. Hence all entrepreneurs contemplating investment would like to obtain credit from financial markets. Standard banks thus anticipate that they will not attract entrepreneurs above a certain quality level, denoted by $\bar{q}$. In the second step, we will discuss whether this is indeed an equilibrium.

The expected profits for standard banks, depending on the quality level $\bar{q}$, are denoted by $G^{b}\left(\bar{q}, R^{b}\right)$ and are given by

$$
G^{b}\left(\bar{q}, R^{b}\right)=\sum_{q_{j}<q^{S B}\left(R^{b}\right)} \gamma_{j}(\alpha I-I-m)+\sum_{\bar{q} \geq q_{j} \geq q^{S B}\left(R^{b}\right)} \gamma_{j}\left(R^{b}-I-m\right)
$$

Let

$$
R^{b *}(\bar{q})=\min \left\{R^{b} \mid G^{b}\left(\bar{q}, R^{b}\right) \geq 0\right\}
$$

Obviously $R^{b *}(\bar{q})$ may not exist. In general, $R^{b *}(\bar{q})$ exists if the pool of investors below $\bar{q}$ is of sufficiently high quality and the monitoring technology in terms of the pair $(\alpha, m)$ is sufficiently effective. Note that

$$
R^{b *}\left(q_{n}\right)=R^{*}=\min \left\{R \mid G^{b}\left(q_{n}, R\right) \geq 0\right\}
$$

We immediately obtain

Lemma 1 Suppose that $R^{b *}\left(\bar{q}^{1}\right)$ exists for some $\bar{q}^{1}<q_{n}$. Then $R^{b *}(\bar{q})$ exists for all $\bar{q} \in\left[\bar{q}^{1}, q_{n}\right]$ and is monotonically decreasing in $\bar{q} \cdot{ }^{12}$

\footnotetext{
${ }^{12}$ Note that $R^{b *}(\bar{q})$ is a step function.
} 
The proof of Lemma 1 follows directly from equation (2). The preceding analysis allows us to establish equilibria when both standard banks and investment banks operating in financial markets compete for borrowers.

Proposition 4 Suppose that $R^{*}$ exists.

(i) If $R^{*}<I+c$, there exists a unique equilibrium in which only standard banks are active and offer debt contracts at a repayment rate of $R^{*}$.

(ii) If $R^{*} \geq I+c$, investment banks will offer debt contracts on behalf of entrepreneurs at a repayment rate of $R^{v *}=I+c$ for all entrepreneurs with

$$
q_{j} \geq q^{F M *}=1+\frac{I+c}{I+z}
$$

a) If $R^{b *}\left(q^{F M *}\right)$ exists, standard banks offer debt contracts at a repayment rate of

$$
R^{b *}\left(q^{F M *}\right)>R^{v *}=I+c
$$

and attract all entrepreneurs with $q_{j}<q^{F M *}$.

b) If $R^{b *}\left(q^{F M *}\right)$ does not exist, standard banks do not offer any contracts, and only entrepreneurs with $q_{j} \geq q^{F M *}$ receive credit contracts.

The proof of Proposition 4 is given in the appendix. The second part of Proposition 4 shows how financial markets and standard banks might coexist. Only entrepreneurs with $q_{j} \geq q^{F M *}$ are able to access financial markets. Entrepreneurs with $q_{j}<q^{F M *}$ face higher repayments but have no other choice than to go to standard banks. As such entrepreneurs will be monitored by standard banks, some of them are willing to invest upon receiving a loan. If monitoring technology in terms of the pair $(\alpha, m)$ is sufficiently effective and the pool of entrepreneurs with $0 \leq q_{j} \leq q^{F M *}$ is sufficiently attractive, then $R^{b *}\left(q^{F M *}\right)$ exists and standard banks and financial markets coexist. 
It is important to stress that the coexistence of standard banks and financial markets does not depend on the cost of monitoring $m$ for standard banks being much smaller than the cost of a creditworthiness test. Suppose, for instance, that $\alpha=1$. Then the equilibrium condition for standard banks amounts to

$$
G^{b}\left(q^{F M *}, R^{b}\right)=\sum_{q^{F M *} \geq q_{j} \geq q^{S B}\left(R^{b}\right)} \gamma_{j}\left(R^{b}-I\right)-m\left(\sum_{q_{j} \leq q^{F M *}} \gamma_{j}\right) \geq 0
$$

Now it is possible for $R^{b *}\left(q^{F M *}\right)$ to exist even if $m \geq c$. For instance, if $m=c$ and the share of entrepreneurs in $\left[1+\frac{2 c}{I+z}, 1+\frac{I+c}{I+z}\right]$ is at least $\frac{1}{2}$, we have $G^{b}\left(q^{F M *}, I+2 c\right) \geq 0$, and hence $R^{b *}$ exists.

Proposition 4 also implies that the presence of investment banks operating in financial markets can lead to a breakdown of financing for the remaining borrowers. This occurs if standard banks face an unattractive pool of entrepreneurs in $\left[q_{1}, q^{F M *}\right]$ and monitoring technologies in terms of $(m, \alpha)$ are not highly effective.

To determine the social efficiency of the presence of financial markets, we recall that savings not channeled to entrepreneurs are invested at the opportunity costs of funds. We denote the welfare in the three different cases by $W^{S B}, W^{S B, F M}$, and $W^{F M}$, respectively. We then obtain

\section{Proposition 5}

(i) If $R^{*}<I+c$, welfare is given by

$$
W^{S B}=\sum_{q_{j} \geq q^{S B}\left(R^{*}\right)} \gamma_{j}\left(q_{j}(I+z)\right)+\sum_{q_{j}<q^{S B}\left(R^{*}\right)} \gamma_{j}(I+z)+(S-I-m)
$$


(ii) If $R^{*} \geq I+c$

a.) If $R^{b *}\left(q^{F M *}\right)$ exists, welfare is given by

$$
\begin{aligned}
W^{S B, F M} & =\sum_{q_{j} \geq q^{S B}\left(R^{b *}\left(q^{F M *}\right)\right)} \gamma_{j}\left(q_{j}(I+z)\right) \\
& +\sum_{q_{j}<q^{S B}\left(R^{b *}\left(q^{F M *}\right)\right)} \gamma_{j}(I+z)+S-I \\
& -c \sum_{q_{j} \geq q^{F M *}} \gamma_{j}-m \sum_{q_{j}<q^{F M *}} \gamma_{j}
\end{aligned}
$$

b.) If $R^{b *}\left(q^{F M *}\right)$ does not exist, welfare is given by

$$
W^{F M}=\sum_{q_{j} \geq q^{F M *}} \gamma_{j}\left(q_{j}(I+z)\right)+\left(S-(I+c) \sum_{q_{j} \geq q^{F M *}} \gamma_{j}\right)+\sum_{q_{j}<q^{F M *}} \gamma_{j} z
$$

The first term in $W^{F M}$ is the value of production from investing entrepreneurs. The last two terms represent the investment of the remaining funds in the frictionless technology and the consumption of the entrepreneurs. The preceding proposition immediately allows us to characterize the constellations in which the joint presence of financial markets and standard banks is socially inefficient. For our main result, we assume for the moment that monitoring and screening costs are sufficiently low and can be disregarded.

Proposition 6 Suppose that initially only standard banks are present. Then the entrance of investment banks operating financial markets is socially inefficient if, and only if,

(i) - entrepreneurs of high quality benefit from and obtain financing through capital markets $\left(R^{*} \geq I+c\right)$ and

- standard banks make non-negative profits with the pool of entrepreneurs who do not have access to capital markets $\left(R^{b *}\left(q^{F M *}\right)\right.$ exists $)$

or 
(ii) - entrepreneurs of high quality benefit from and obtain financing through capital markets $\left(R^{*} \geq I+c\right)$,

- standard banks cannot make non-negative profits with the remaining pool of entrepreneurs who do not have access to capital markets and drop out $\left(R^{b *}\left(q^{F M *}\right)\right.$ does not exist $)$, and

- entrepreneurs of higher quality than those investing with standard banks alone obtain capital market financing $\left(R^{*}-\alpha I<I+c\right)$.

The proof of Proposition 6 is given in the appendix. We observe that the presence of investment banks operating financial markets is socially inefficient in two cases. In particular, if standard banks and financial markets coexist, the outcome is necessarily socially inefficient. ${ }^{13}$

The presence of financial markets is irrelevant if screening costs are sufficiently high and socially efficient if screening costs are sufficiently low, such that standard banks drop out of the market and more intermediate quality borrowers will obtain credit than with standard banks alone, i.e. if $q^{F M *}<q^{S B}\left(R^{*}\right)$.

In Proposition 6, we have neglected monitoring and screening costs. We now discuss how our results need to be modified in the presence of such costs. Clearly, the first point in Proposition 6 holds under the stated assumptions if $m \leq c$, since the presence of financial markets would increase resource costs for banking activities. The second part holds as long as investment gains under standard banks outweigh the potential savings of screening costs when only investment banks operating in financial markets are present. ${ }^{14}$

The last two propositions illustrate that there is a non-monotonical relationship between the efficiency of the monitoring technology of investment banks operating in financial markets and social welfare. Suppose that for investment banks the cost $c$ of judging investment projects is sufficiently high, so

\footnotetext{
${ }^{13}$ If the opportunity cost of funds is positive, we obtain a countervailing effect since shirkers no longer generate the opportunity cost of funds. However, the presence of financial markets is still inefficient if the share of intermediate quality borrowers is sufficiently large.

${ }^{14}$ Savings of screening costs occur if $c<m$ or $c>m$ and $m>c \sum_{q_{j} \geq q^{F M *}} \gamma_{j}$.
} 
that $R^{*}<I+c$. Standard banks will then offer credit to all entrepreneurs. If $c$ declines to a level that permits the coexistence of standard banks and financial markets or drives standard banks out of the market, the resulting allocation is less efficient. If, however, $c$ shrinks even more, investment banks will reduce repayments to entrepreneurs for whom they issue debt contracts, thus allowing more entrepreneurs to obtain credit, which is socially more beneficial.

There have been many debates about the historical absence in continental Europe of certain types of financial intermediaries, such as venture capitalists or highly developed markets for investment banks. This is often ascribed to regulations rather than to a lack of entrepreneurial spirit. One interpretation in the light of the arguments set out above is that such a situation may protect standard banks. If financial markets were to develop for the same borrower classes, it could destroy existing credit markets. Clearly, other arguments need to be added in order to obtain a balanced perspective on such policy issues. However, our theoretical predictions show that the introduction of banks specializing in creditworthiness tests may hamper the functioning of credit markets, even if the available monitoring technologies of financial intermediaries improve.

\section{Sophisticated Banks}

Finally, let us consider a sophisticated financial intermediary that has access to both types of monitoring technologies. The development of such banks is the objective of the new framework for banking regulation known as Basel II. Consider a situation where initially only standard banks are present. How sophisticated banks behave in competition with standard banks depends crucially on parameter comparisons. Let us consider this in more detail.

Suppose sophisticated banks can use both monitoring technologies. Bertrand competition ensures that repayments are $I+c+m$. A sophisticated bank will be able to finance all entrepreneurs of a quality above a critical level, denoted 
by $q^{\text {soph }}$, and given by

$$
\begin{aligned}
q^{\text {soph }}(I+z)-(I+c+m) & =(1-\alpha) \cdot I+z \\
q^{\text {soph }} & =1+\frac{I+c+m-\alpha I}{I+z}
\end{aligned}
$$

Hence a sophisticated bank can offer credit contracts such that all entrepreneurs who turn out to have a quality above $q^{\text {soph }}$ in the creditworthiness test will obtain loans. Bertrand competition ensures that the repayment sophisticated banks offer to such entrepreneurs is equal to $I+c+m$.

We now characterize the equilibrium behavior of sophisticated banks. Since sophisticated banks can behave as investment banks, standard banks, or genuinely sophisticated banks, we can directly formulate the coexistence result in the following Proposition, which is proved in the appendix.

Proposition 7 Suppose that $R^{*}$ exists

(i) If $R^{*}<I+c$, only standard banks and sophisticated banks acting as standard banks are active and offer debt contracts at $R^{*}$.

(ii) If $R^{*} \geq I+c$, investment banks and sophisticated banks acting as investment banks offer debt contracts at $R^{v *}=I+c$ for all entrepreneurs with $q_{j} \geq q^{F M *}$

a.) If $R^{b *}\left(q^{F M *}\right)$ exists and if $R^{b *}\left(q^{F M *}\right)<I+c+m$, standard banks and sophisticated banks behaving as standard banks offer debt contracts at $R^{b *}\left(q^{F M *}\right)$

b.) If $R^{b *}\left(q^{F M *}\right)$ does not exist or if $R^{b *}\left(q^{F M *}\right) \geq I+c+m$, sophisticated banks offer debt contracts at repayment $R^{\text {soph* }}=I+c+m$ for entrepreneurs with $q^{\text {soph }} \leq q_{j}<q^{F M *}$ Standard banks are not active. 
The preceding proposition shows that standard banks and sophisticated banks can never coexist. If $R^{*} \geq I+c$, sophisticated banks may act as investment banks operating financial markets and as standard banks for the remaining entrepreneurs. Hence in this case they would produce the same social inefficiencies as discussed in the previous section. Alternatively, they apply both types of monitoring technologies, which may be socially efficient. ${ }^{15}$ The former case indicates that regulation such as Basel II, aimed at increasing the sophistication of banks, may lead to welfare losses if monitoring technologies are not efficient enough.

\section{Conclusion}

In this paper we have identified a potential problem when capital markets operated by investment banks and standard commercial banks compete. If standard banks face competition from financial markets in which investment banks perform creditworthiness tests, welfare may decrease. Since financial markets can attract the highest quality borrowers, standard banks are forced to increase repayments. This, in turn, leads to less productive investments. We have outlined potential applications of the coexistence problem of financial intermediaries and financial markets when regulations aim to increase the sophistication of financial institutions.

\footnotetext{
${ }^{15}$ The condition is $q^{S B}\left(R^{*}\right)>q^{\text {soph }}$.
} 


\section{Appendix}

\section{Proof of Proposition 3}

It is obvious that Bertrand competition ensures $R_{q_{j}}=I+c$ for all investing entrepreneurs if the investment is riskless. Repayments in this case must cover the opportunity cost of funds and the resources needed to perform creditworthiness tests. Given the repayment $R^{v *}=I+c$, the lowest quality entrepreneur who still invests is determined by $q^{F M *}(I+z)-R^{v *}=I+z$, which implies $q^{F M *}=1+\frac{I+c}{I+z}$. Hence, for $q \geq q^{F M *}$ the investment is indeed riskless.

\section{Proof of Proposition 4}

(i) The first point follows directly, since financial markets could not attract any entrepreneurs. In turn, if investment banks offer $R^{v *}=I+c$ in financial markets, standard banks can successfully undercut them in terms of repayments and attract all investors.

(ii) If $R^{*} \geq I+c$, competition between investment banks in financial markets requires that $R^{v *}=I+c$. Since $R^{b *}\left(q_{n}\right)=R^{*}>R^{v *}$ and $R^{b *}$ is monotonically decreasing in $q$, standard banks can never successfully undercut investment banks operating in financial markets. Hence all entrepreneurs with $q_{j} \geq q^{F M *}$ will be attracted by financial markets. Standard banks will enter and offer credit contracts to the remaining population of entrepreneurs if, and only if, they can make non-negative profits and hence if, and only if, $R^{b *}\left(q^{F M *}\right)$ exists. This implies (ii)a and (ii)b. If $R^{b *}\left(q^{F M *}\right)$ exists, the competition of standard banks will induce each standard bank to charge $R^{b *}\left(q^{F M *}\right)$ in equilibrium, as discussed earlier in the paper. 


\section{Proof of Proposition 6}

There are two cases where the entrance of investment banks operating financial markets is socially inefficient. The first case is characterized as follows:

- high-quality entrepreneurs benefit from, and obtain financing through, capital markets $\left(R^{*} \geq I+c\right)$, and

- standard banks can make positive or zero profits with the pool of entrepreneurs who do not have access to capital markets. The relevant condition is that $R^{b *}\left(q^{F M *}\right)$ exists.

Since standard banks need to offer higher repayments to the remaining pool of borrowers $\left(R^{b *}\left(q^{F M *}\right)>R^{*}\right)$, entrepreneurs using standard banks have less incentive to invest. As high-quality entrepreneurs lured away by investment banks would have also invested if standard banks were present on their own, the entrance of investment banks decreases the overall share of investing entrepreneurs and is therefore inefficient. This proves the first case. The second case is characterized as follows:

- high-quality entrepreneurs with high quality benefit from, and obtain financing through, capital markets $\left(R^{*} \geq I+c\right)$,

- standard banks cannot make non-negative profits with the remaining pool of entrepreneurs and drop out $\left(R^{b *}\left(q^{F M *}\right)\right.$ does not exist), and

- only entrepreneurs of higher quality than those investing with the standard bank alone obtain financing through capital markets. The relevant condition is $q^{S B}\left(R^{*}\right)<q^{F M *}$, which translates into $R^{*}-\alpha I<I+c$.

In the second case, financial markets cause the exit of standard banks. As only high-quality entrepreneurs have access to financial markets, the share of investing entrepreneurs decreases, as intermediate entrepreneurs who would invest with standard banks alone do not have access to credit. 


\section{Proof of Proposition 7}

The first point (i) is clear. For (ii) we observe that sophisticated banks have no incentive to monitor entrepreneurs with $q_{j} \geq q^{F M *}$, as standard banks do, as such entrepreneurs will invest anyway. Hence for such entrepreneurs, sophisticated banks imitate investment banks and require a repayment of $R^{o *}=I+c$. Next, we note that our general assumption $\alpha I>m$ implies that $q^{\text {soph }}<q^{F M *}$. Hence for the range of quality levels $\left[q^{s o p h}, q^{F M *}\right)$ sophisticated banks apply both monitoring technologies to an individual entrepreneur, as otherwise such entrepreneurs would shirk. If, however, $R^{b *}\left(q^{F M *}\right)<I+c+m$, standard banks that perform no creditworthiness test can offer better terms for the whole pool of entrepreneurs. Therefore sophisticated banks imitate standard banks for the pool of investors who do not apply for creditworthiness tests.

If $R^{b *}\left(q^{F M *}\right)$ does not exist, standard banks are not active, and sophisticated banks offer a second type of debt contract to entrepreneurs with $q^{\text {soph }} \leq$ $q_{j}<q^{F M *}$ at repayment $R^{s o p h *}=I+c+m$. Such entrepreneurs are screened and monitored to avoid shirking. Sophisticated banks act like truly sophisticated banks.

Finally, we discuss the case where $R^{b *}\left(q^{F M *}\right)$ exists and is larger than $I+c+m$. We note that

$$
q^{S B}\left(R^{b *}\left(q^{F M *}\right)\right)=1+\frac{R^{b *}\left(q^{F M *}\right)-\alpha I}{I+z} \geq 1+\frac{I+c+m-\alpha I}{I+z}=q^{s o p h}
$$

Hence standard banks would only have shirkers in the remaining pool of entrepreneurs $\left[q_{1}, q^{s o p h}\right]$ and accordingly drop out of the market. 


\section{References}

[1] Allen, F. and D. Gale (2004), "Financial Intermediaries and Markets", Econometrica, 72(4), 1023-1061.

[2] Allen, F., and A.M. Santomero (1998), "A Theory of Financial Intermediation", Journal of Banking and Finance, 21, 1461-1485.

[3] Beatty, R., and J.R. Ritter (1986), "Investment Banking, Reputation, and the Underpricing of Initial Public Offerings", Journal of Financial Economics, 15, 213-232.

[4] Berger, A.N., and G.F. Udell (2002), "Small Business Credit Availability and Relationship Lending: The Importance of Bank Orgnisational Structure", The Economic Journal, 112(447), F32-F53.

[5] Berger, A.N., R.S. Demsetz and P. Strahan (1998), "The Consolidation of the Financial Services Industry: Causes, Consequences, and Implications for the Future", Federal Reserve Bank of New York.

[6] Berger, A.N. (2000), "The Integration of the Financial Services Industry: Where are the Efficiencies?", FEDS Paper, No. 2000-36.

[7] Besanko, D. G., and G. Kanatas (1993), "Credit Market Equilibrium with Bank Monitoring and Moral Hazard", Review of Financial Studies, 6, 213232.

[8] Bester, H. (1985), "Screening versus Rationing in Credit Markets with Imperfect Competition", American Economic Review, 75, 850-855.

[9] Bester, H. (1987), "The Role of Collateral in Credit Markets with Imperfect Information", European Economic Review, 31, 887-899.

[10] Bhattacharya, S., and A.V. Thakor (1993), "Contemporary Banking Theory", Journal of Financial Intermediation, 3, 2-50. 
[11] Bhattacharya, S., A.W.A. Boot and A.V. Thakor (1998), "The Economics of Bank Regulation", Journal of Money Credit and Banking, 30(4), 745-770.

[12] Black, B.S., and R.J. Gilson (1998), "Venture Capital and the Structure of Capital Markets: Banks versus Stock Markets", Journal of Financial Economics, 47, 243-277.

[13] Bolton, P., and X. Freixas (2000), "Equity, Bonds, and Bank Debt: Capital Structure and Financial Market Equilibrium Under Asymmetric Information", Journal of Political Economy, 108 (2), 324-351.

[14] Boot, W.A., and A.V. Thakor (1997a), "Financial System Architecture", Review of Financial Studies, 10, 693-733.

[15] Boot, W.A., and A.V. Thakor (1997b), "Banking Scope and Financial Innovation", Review of Financial Studies, 10, 1099-1131.

[16] Boot, A.W.A., and A.V. Thakor (2000), "Can Relationship Banking Survive Competition?", Journal of Finance, 55, 2, 679-713.

[17] Boot, A.W.A. (2000), "Relationship Banking: What Do We Know?", Journal of Financial Intermediation, 9 (1), 7-15.

[18] Booth, J.R., and R.L. Smith (1986), "Capital Raising, Underwriting, and the Certification Hypothesis, Journal of Financial Economics, 15, 261-281.

[19] Bröcker, T., (1990), "Credit-Worthiness Tests and Interbank Competition", Econometrica, 58, 429-452.

[20] Carter, R., and S. Manaster (1990), "Initial Public Offerings and Underwriter Reputation", Journal of Finance, 45, 1045-1067.

[21] Chemmanur, T.J., and P. Fulghieri (1994), "Investment Bank Reputation, Information Production, and Financial Intermediation", Journal of Finance, 49, 57-79. 
[22] Diamond, D. W. (1984), "Financial Intermediation and Delegated Monitoring", Review of Economic Studies 51, 393-414.

[23] Gersbach, H., and H. Uhlig (2004), "Debt Contracts and Collapse as Equilibrium Phenomena", Journal of Financial Intermediation, forthcoming.

[24] Hellwig, M. (1987), "Some Recent Developments in the Theory of Competition in Markets with Adverse Selection", European Economic Review, 31, 319-325.

[25] Hellwig, M. (1994), "Banking and Finance at the End of the Twentieth Century", WWZ-Discussion Paper, No. 9426, University of Basel.

[26] Holmström, B., and J. Tirole (1997), "Financial Intermediation, Loanable Funds and the Real Sector", The Quarterly Journal of Economics, 112(3), 663-691.

[27] Hoshi, T., D.S. Scharfstein and A. Kashyap (1993), "The Choice Between Public and Private Debt: An Examination of Post-Deregulation Corporate Financing in Japan", NBER Working Paper Series, No. 4421.

[28] James, C.M. (1987), "Some Evidence on the Uniqueness of Bank Loans", Journal of Financial Economics, 19, 217-235.

[29] Kanatas, G., and J. Qi (1998), "Underwriting by Commercial Banks: Incentive Conflicts, Scope Economies, and Project Quality", Journal of Money, Credit, and Banking, 30, 119-133.

[30] Kanatas, G., and J. Qi (2000), "Banking Scope and Information Production", Working Paper, Rice University.

[31] Kroszner, R., and R. Rajan (1994), "Is the Glas-Steagall Act Justified? A Study of the US Experience With Unilateral Banking Before 1933", American Economic Review, 84, 810-832. 
[32] Lummer, S.L., and J.J. McConnell (1989), "Further Evidence on the Bank Lending Process and the Capital-Market Response to Bank Loan Agreements", Journal of Financial Economics, 25, 99-122.

[33] Petersen, M.A. (2004), "Information: Hard and soft", mimeo, Kellog School of Management, Northwestern University.

[34] Puri, M. (1994), "The Long-Term Default Performance of Bank Underwritten Security Issues", Journal of Banking and Finance, 18, 397-418.

[35] Puri, M. (1999), "Commercial Banks as Underwriters: Implications for the Going Public Process", Journal of Financial Economics, 40, 373-401.

[36] Repullo, R., and J. Suarez (2000), "Entrepreneurial moral hazard and bank monitoring: A model of the credit channel", European Economic Review, 44(10),1931-1950.

[37] Rothschild, M., and J. Stiglitz (1976), "Equilibrium in Competitive Insurance Markets: An Essay of the Economics of Imperfect Information", Quarterly Journal of Economics, 80, 629-49.

[38] Stiglitz, J., and A. Weiss (1981), "Credit Rationing in Markets with Imperfect Information", American Economic Review, 71, 393-410.

[39] von Thadden, E.L. (1999), "Liquidity Creation through Banks and Markets: Multiple Insurance and Limited Market Access", European Economic Review, Vol. 43, 991-1006. 


\section{SFB 649 Discussion Paper Series 2006}

For a complete list of Discussion Papers published by the SFB 649, please visit http://sfb649.wiwi.hu-berlin.de.

001 "Calibration Risk for Exotic Options" by Kai Detlefsen and Wolfgang K. Härdle, January 2006.

002 "Calibration Design of Implied Volatility Surfaces" by Kai Detlefsen and Wolfgang K. Härdle, January 2006.

003 "On the Appropriateness of Inappropriate VaR Models" by Wolfgang Härdle, Zdeněk Hlávka and Gerhard Stahl, January 2006.

004 "Regional Labor Markets, Network Externalities and Migration: The Case of German Reunification" by Harald Uhlig, January/February 2006.

005 "British Interest Rate Convergence between the US and Europe: A Recursive Cointegration Analysis" by Enzo Weber, January 2006.

006 "A Combined Approach for Segment-Specific Analysis of Market Basket Data" by Yasemin Boztuğ and Thomas Reutterer, January 2006.

007 "Robust utility maximization in a stochastic factor model" by Daniel Hernández-Hernández and Alexander Schied, January 2006.

008 "Economic Growth of Agglomerations and Geographic Concentration of Industries - Evidence for Germany" by Kurt Geppert, Martin Gornig and Axel Werwatz, January 2006.

009 "Institutions, Bargaining Power and Labor Shares" by Benjamin Bental and Dominique Demougin, January 2006.

010 "Common Functional Principal Components" by Michal Benko, Wolfgang Härdle and Alois Kneip, Jauary 2006.

011 "VAR Modeling for Dynamic Semiparametric Factors of Volatility Strings" by Ralf Brüggemann, Wolfgang Härdle, Julius Mungo and Carsten Trenkler, February 2006.

012 "Bootstrapping Systems Cointegration Tests with a Prior Adjustment for Deterministic Terms" by Carsten Trenkler, February 2006.

013 "Penalties and Optimality in Financial Contracts: Taking Stock" by Michel A. Robe, Eva-Maria Steiger and Pierre-Armand Michel, February 2006.

014 "Core Labour Standards and FDI: Friends or Foes? The Case of Child Labour" by Sebastian Braun, February 2006.

015 "Graphical Data Representation in Bankruptcy Analysis" by Wolfgang Härdle, Rouslan Moro and Dorothea Schäfer, February 2006.

016 "Fiscal Policy Effects in the European Union" by Andreas Thams, February 2006.

017 "Estimation with the Nested Logit Model: Specifications and Software Particularities" by Nadja Silberhorn, Yasemin Boztuğ and Lutz Hildebrandt, March 2006.

018 "The Bologna Process: How student mobility affects multi-cultural skills and educational quality" by Lydia Mechtenberg and Roland Strausz, March 2006.

019 "Cheap Talk in the Classroom" by Lydia Mechtenberg, March 2006.

020 "Time Dependent Relative Risk Aversion" by Enzo Giacomini, Michael Handel and Wolfgang Härdle, March 2006.

021 "Finite Sample Properties of Impulse Response Intervals in SVECMs with Long-Run Identifying Restrictions" by Ralf Brüggemann, March 2006.

022 "Barrier Option Hedging under Constraints: A Viscosity Approach" by Imen Bentahar and Bruno Bouchard, March 2006.

\section{SFB 649, Spandauer Straße 1, D-10178 Berlin} http:/ / sfb649.wiwi.hu-berlin.de

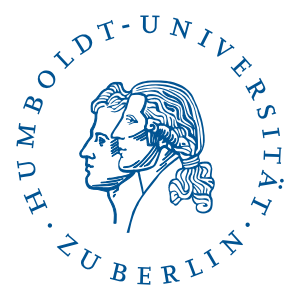


023 "How Far Are We From The Slippery Slope? The Laffer Curve Revisited" by Mathias Trabandt and Harald Uhlig, April 2006.

024 "e-Learning Statistics - A Selective Review" by Wolfgang Härdle, Sigbert Klinke and Uwe Ziegenhagen, April 2006.

025 "Macroeconomic Regime Switches and Speculative Attacks" by Bartosz Maćkowiak, April 2006.

026 "External Shocks, U.S. Monetary Policy and Macroeconomic Fluctuations in Emerging Markets" by Bartosz Maćkowiak, April 2006.

027 "Institutional Competition, Political Process and Holdup" by Bruno Deffains and Dominique Demougin, April 2006.

028 "Technological Choice under Organizational Diseconomies of Scale" by Dominique Demougin and Anja Schöttner, April 2006.

029 "Tail Conditional Expectation for vector-valued Risks" by Imen Bentahar, April 2006.

030 "Approximate Solutions to Dynamic Models - Linear Methods" by Harald Uhlig, April 2006.

031 "Exploratory Graphics of a Financial Dataset" by Antony Unwin, Martin Theus and Wolfgang Härdle, April 2006.

032 "When did the 2001 recession really start?" by Jörg Polzehl, Vladimir Spokoiny and Cătălin Stărică, April 2006.

033 "Varying coefficient GARCH versus local constant volatility modeling. Comparison of the predictive power" by Jörg Polzehl and Vladimir Spokoiny, April 2006.

034 "Spectral calibration of exponential Lévy Models [1]" by Denis Belomestny and Markus Reiß, April 2006.

035 "Spectral calibration of exponential Lévy Models [2]" by Denis Belomestny and Markus Reiß, April 2006.

036 "Spatial aggregation of local likelihood estimates with applications to classification" by Denis Belomestny and Vladimir Spokoiny, April 2006.

037 "A jump-diffusion Libor model and its robust calibration" by Denis Belomestny and John Schoenmakers, April 2006.

038 "Adaptive Simulation Algorithms for Pricing American and Bermudan Options by Local Analysis of Financial Market" by Denis Belomestny and Grigori N. Milstein, April 2006.

039 "Macroeconomic Integration in Asia Pacific: Common Stochastic Trends and Business Cycle Coherence" by Enzo Weber, May 2006.

040 "In Search of Non-Gaussian Components of a High-Dimensional Distribution" by Gilles Blanchard, Motoaki Kawanabe, Masashi Sugiyama, Vladimir Spokoiny and Klaus-Robert Müller, May 2006.

041 "Forward and reverse representations for Markov chains" by Grigori N. Milstein, John G. M. Schoenmakers and Vladimir Spokoiny, May 2006.

042 "Discussion of 'The Source of Historical Economic Fluctuations: An Analysis using Long-Run Restrictions' by Neville Francis and Valerie A. Ramey" by Harald Uhlig, May 2006.

043 "An Iteration Procedure for Solving Integral Equations Related to Optimal Stopping Problems" by Denis Belomestny and Pavel V. Gapeev, May 2006.

044 "East Germany's Wage Gap: A non-parametric decomposition based on establishment characteristics" by Bernd Görzig, Martin Gornig and Axel Werwatz, May 2006.

045 "Firm Specific Wage Spread in Germany - Decomposition of regional differences in inter firm wage dispersion" by Bernd Görzig, Martin Gornig and Axel Werwatz, May 2006.

\section{SFB 649, Spandauer Straße 1, D-10178 Berlin http:/ / sfb649.wiwi.hu-berlin.de}

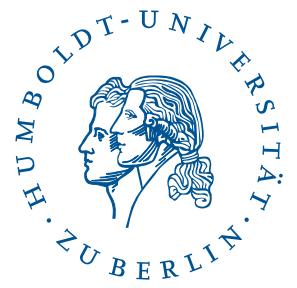


046 "Produktdiversifizierung: Haben die ostdeutschen Unternehmen den Anschluss an den Westen geschafft? - Eine vergleichende Analyse mit Mikrodaten der amtlichen Statistik" by Bernd Görzig, Martin Gornig and Axel Werwatz, May 2006.

047 "The Division of Ownership in New Ventures" by Dominique Demougin and Oliver Fabel, June 2006.

048 "The Anglo-German Industrial Productivity Paradox, 1895-1938: A Restatement and a Possible Resolution" by Albrecht Ritschl, May 2006.

049 "The Influence of Information Costs on the Integration of Financial Markets: Northern Europe, 1350-1560" by Oliver Volckart, May 2006.

050 "Robust Econometrics" by Pavel Čížek and Wolfgang Härdle, June 2006.

051 "Regression methods in pricing American and Bermudan options using consumption processes" by Denis Belomestny, Grigori N. Milstein and Vladimir Spokoiny, July 2006.

052 "Forecasting the Term Structure of Variance Swaps" by Kai Detlefsen and Wolfgang Härdle, July 2006.

053 "Governance: Who Controls Matters" by Bruno Deffains and Dominique Demougin, July 2006.

054 "On the Coexistence of Banks and Markets" by Hans Gersbach and Harald Uhlig, August 2006.

SFB 649, Spandauer Straße 1, D-10178 Berlin http:/ / sfb649.wiwi.hu-berlin.de

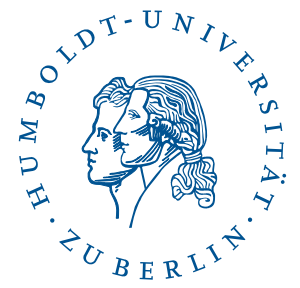

